\title{
The Effect of Country-of-Origin Image on Purchase Intention. The Mediating Role of Perceived Quality and Perceived Price
}

\author{
Amina Merabet
}

\begin{abstract}
This study aims to evaluate the impact of Country-of-origin image on purchase intention through two mediating variables (perceived quality and perceived price).

After a short literature review, an empirical study was conducted among 120 participants. Results indicate that the country-of-origin Image has a positive impact on perceived quality and perceived price. They also highlight the mediating role of perceived price in the relationship between Country-of-origin image and purchase intention.
\end{abstract}

Index Terms - Country-of-origin image - perceived qualityperceived price- purchase intention.

\section{INTRODUCTION}

The changes in the economic environment due to globalization and the development of Internet have fully changed consumer behavior. Today, Consumers are faced to an ample supply and a significant rise of brands. In fact, they must choose between many products with different origins [1]. As a result, connotations of images of products, brands, and countries are developed and affect their perceptions and purchasing behavior. It refers to Country-of-origin image or "made-in" which represents the country of production or assembly. It can be explained by the tendency of consumers to stereotype countries. For example, French products with luxury, products from developing countries are generally perceived as negative, etc. [2].

Country-of-origin image is one of the explanatory factors of purchasing decisions and constitutes an intangible barrier to access foreign markets.

The literature on the effects of Country-of-origin image is very wide and has interested many researchers for almost forty years (ex: [1], [3]-[8] etc.),however, few researches have focused on Algerian context. In order to fill the gap, this paper aims to:

- study the impact of Country-of-origin image purchase intention.

- Test de mediating role of perceived quality and perceived price

After a short review, we will present the conceptual model and the research hypotheses, and finally, we will present the research methodology and the results of the empirical study.

Published on November 2, 2020.

Amina Merabet, Tlemcen university, Mecas laboratory, Algeria.

(corresponding e-mail: aminamerabet1982@gmail.com)

\section{LITERATURE REVIEW AND CONCEPTUAL MODEL}

\section{A. Country-of-Origin Image (Made-In)}

Nagashima [9] one of the pioneers in this research area defines Country-of-origin image as "the picture, the reputation, and the stereotype that businessmen and consumers attach to the products of a specific country. This image is created by such variables as representative products, national characteristics, economic and political background; history and traditions." It represents the set of descriptive, differential and informational beliefs that an individual might have toward a given country" [10].

This image generally finds its sources in direct experience with the country through travel but also on the basis of word of mouth, readings, media, etc. [11].

The effects of the country of origin on consumer behavior vary from country to country due to differences in economic, socio-cultural, and other factors.

\section{B. Perceived Quality and Country-of-Origin}

The perceived quality represents all the perceptible, sensitive, and sensory dimensions of the product or service. So, it refers to a global system of judgment and lead to consumer satisfaction.

According to Zeithaml [12] perceived quality can be defined as "an overall judgment concerning the excellence or superiority of a product or service". Consumers are increasingly demanding quality, and they are ready to pay more for better products. Consumer decision is based on product quality according to an acquisition and integration process of information about products or services.

In fact, the country of origin be a quality indicator.

\section{Perceived Price and Country-of-Origin Image}

Zeithaml [12] has defined Perceived price as “customer's subjective perception of what is given up or sacrificed to acquire the product'. It is the nominal value charged to the customer in order to acquire products and to be benefited from the ownership or use of products [13].

Most of customers give subjective value for products like: "expensive" or "cheap" and do not recall or recognize the objective price.

Thus, the sacrifice of something made by customers in order to acquire product or service include nominal monetary price, and non-monetary costs (time cost, physical effort or energy, and learning cost) made during purchasing [12].

The effect of the country-of-origin image on the perceived price has been studied many times. 


\section{Purchase Intention}

The purchase intention is a very complex concept. Some researchers consider it as a component of the attitude which is relative to the conative dimension [14], [15]. While others examine it as an independent variable [16], [17]. According to Duhaime et al. [18], the purchase intention consists of the stage of the decision-making process where the customer is able to specify his preference for a product based on his experience, beliefs and attitudes.

Two different approaches can explain the purchase intention: the planning approach and the probabilistic approach.

- The planning approach [19]-[22]: It reflects the dynamic side of this concept and the degree which a person has formulated conscious plans to perform or not perform some specified future behavior"[23]. For Howard [21], purchase intention is the process of planning a purchase. It is the result of a cognitively processed desire or need that leads to purchase planning [20].

- The probabilistic approach

Other researchers (e.g. [24]-[27] etc.) prefer the probabilistic dimension of intention. It is "the subjective probability of purchasing a given product or a given brand" [26]. Everyone determines this probability by himself [28]. We will adopt this approach in our research.

There is no doubt that Country-of-origin image influences consumers' perception of products, and which subsequently influences the decision to buy a product or service.

In view of the above, we can propose the following hypotheses:

- H1: Country-of-origin image has a positive impact on the perceived quality of products.

- H2: Country-of-origin image have a positive impact on perceived price

- H3: Perceived quality has a positive impact on purchase intention.

- H4: Perceived price has a positive impact on purchase intention

- H5: Perceived quality is a mediator variable in the relationship between Country-of-origin image and purchase intention.

- H6: Perceived price is a mediator variable in the relationship between Country-of-origin image and purchase intention.

The conceptual model is illustrated in Fig. 1.

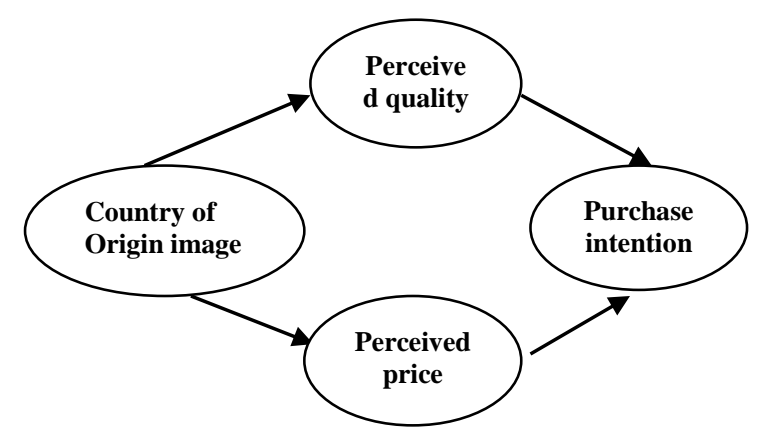

Fig. 1. Conceptual model.

\section{EMPIRICAL STUDY}

\section{A. Research Method}

We have choice Raylan brand. It is an Algerian brand of electrical household appliances. The scales used are taken from the literature:

- Perceived quality: Yoo and Donthu[29] scale (2 items).

- Purchasing intention (PI): Dodds et al. [30] scale (3 items).

- Perceived price: Berkowitz and Walton [31] scale (3 items).

- Country-of-origin image: inspired from (5 items).

The data are collected by online survey from a random sample of 120 Algerian people aged over 18 years ago.

\section{B. Results and Discussion}

We have tested our hypotheses using structural equations modeling. The PLS approach with the maximum likelihood method was chosen because it is highly used in marketing research and it is adapted to small sample.

After deleting 2 items (PP1 and COI5) we obtained a very satisfactory reliability and validity indices. It is shown the internal consistency of all the scales (See Table I and Table II).

TABLE I: RELIABILITY AND VALIDITY OF THE CONSTRUCT

\begin{tabular}{ccccc}
\hline \hline & $\begin{array}{c}\text { Average } \\
\text { variance } \\
\text { extracted } \\
\text { (AVE) }\end{array}$ & $\begin{array}{c}\text { Composite } \\
\text { reliability }\end{array}$ & Rho-a & $\begin{array}{c}\text { Cronbach's } \\
\text { alpha }\end{array}$ \\
\hline COI & 0.587 & 0.850 & 0.768 & 0.765 \\
PI & 0.680 & 0.862 & 0.842 & 0.764 \\
PP & 0.855 & 0.922 & 0.831 & 0.830 \\
PQ & 0.782 & 0.878 & 0.745 & 0.724 \\
\hline \hline
\end{tabular}

TABLE II: DISCRIMINANT VALIDITY (FORNELL-LARCKERCRITERION)

\begin{tabular}{ccccc}
\multicolumn{6}{c}{ TABLE II: DISCRIMINANT VALIDITY } & FORNELL-LARCKERCRITERION) \\
\hline \hline & COI & PI & PP & PQ \\
\hline COI & 0.766 & & & \\
PI & 0.556 & 0.824 & & \\
PP & 0.510 & 0.976 & 0.924 & 0.884 \\
PQ & 0.704 & 0.689 & 0.650 & 0 \\
\hline \hline
\end{tabular}

The values of R2 (COI-PQ $=0.496$; COI-PP $=0.260$; PQ$\mathrm{PI}=0.959$; $\mathrm{PP}-\mathrm{PI}=0.959)$ are above the recommended threshold by researchers $(\mathrm{R} 2=0.2)$ (see Table III). So, we can undertake the analysis.

\begin{tabular}{ccc}
\multicolumn{3}{c}{ TABLE III: R SQUARE } \\
\hline \hline R Square & R Square Adjusted \\
\hline PP & 0.959 & 0.958 \\
PQ & 0.260 & 0.251 \\
\hline \hline
\end{tabular}

The results in Fig. 2 and 3 and Table IV and V indicate that:

- Country-of-origin image has a positive influence on perceived quality $\left(\mathrm{R}^{2}=0.497, \beta=0.704, \mathrm{~T}=13.058\right.$, $\mathrm{P}=0.000)$. These results support the conclusions of several researchers: [32], [33], so H1 is confirmed.

- There is a positive link between country-of-origin image and perceived price $\left(\mathrm{R}^{2}=0.260 ; \beta=0.510, \mathrm{~T}=7.303\right.$, 
$\mathrm{P}=0.000)$. Consequently, $\mathrm{H} 2$ is confirmed. These finding support the conclusions of several researchers [34], [35].

- Purchase intention is influenced by perceived price $\left(\mathrm{R}^{2}\right.$ $=0.959 ; \beta=0.915, \mathrm{~T}=34.142, \mathrm{P}=0.000)$ unlike perceived quality $\left(\mathrm{R}^{2}=0.959, \beta=0.094, \mathrm{~T}=2.694, \mathrm{P}=0.000\right)$ which is in contrast with previous studies. So $\mathrm{H} 3$ is confirmed while $\mathrm{H} 4$ is rejected.

- The mediating role of perceived price is confirmed $(\beta=$ 0.466) (see table VI).

- That Perceived quality is not a mediator variable in the relationship between Country-of-origin image and purchase intention as the direct effect of Perceived quality on purchase intention is rejected $(\beta=0.066)$ (see Table VI).

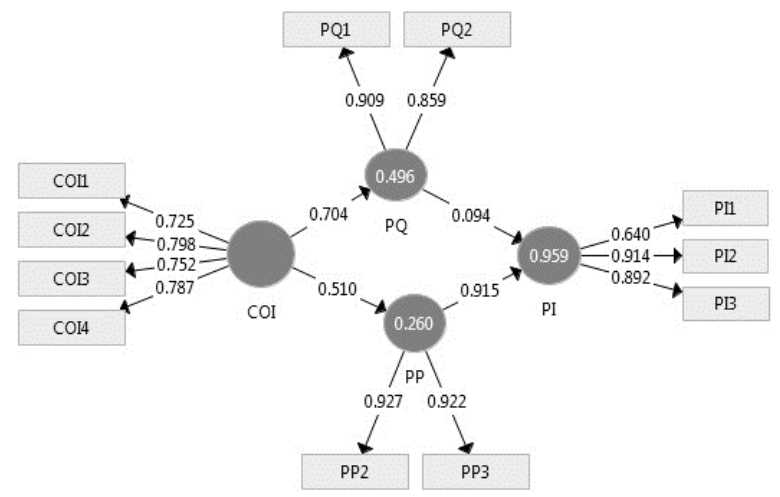

Fig.2.Structural model results.

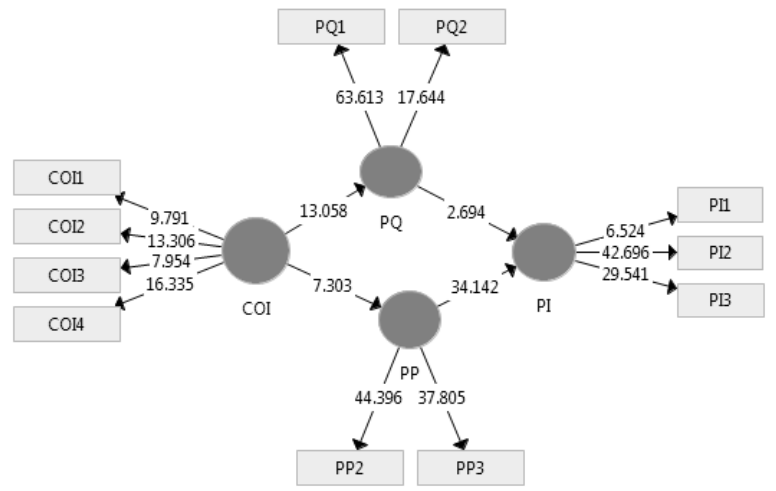

Fig.3. Structural model with bootstrapping procedure results.

TABLE IV: TOTAL EFFECTS

\begin{tabular}{ccccc}
\multicolumn{5}{c}{ TABLE IV: TOTAL EFFECTS } \\
\hline \hline COI & COI & PI & PP & PQ \\
PI & 0.766 & 0.704 & 0.510 & 0.533 \\
PP & 0.556 & & & \\
PQ & 0.510 & & & 0.915 \\
\hline \hline
\end{tabular}

TABLE V: BOOTSTRAPPING TOTAL EFFECTS

\begin{tabular}{cccccc}
\hline & $\begin{array}{c}\text { Original } \\
\text { Sample }\end{array}$ & $\begin{array}{c}\text { Original } \\
\text { Sample }\end{array}$ & $\begin{array}{c}\text { Standard } \\
\text { Deviation }\end{array}$ & $\begin{array}{c}\mathrm{T} \\
\text { Statistics }\end{array}$ & $\begin{array}{c}\mathrm{P} \\
\text { Values }\end{array}$ \\
\hline COI->PP & 0.510 & 0.513 & 0.070 & 7.303 & 0.000 \\
PI->PQ & 0.704 & 0.710 & 0.054 & 13.058 & 0.000 \\
PP->PI & 0.915 & 0.915 & 0.027 & 34.142 & 0.000 \\
PQ->PI & 0.094 & 0.095 & 0.035 & 2.694 & 0.000 \\
\hline \hline
\end{tabular}
Prentice-Hall, Englewood Cliffs, 1996.

[14] A. G. Greenwald, "What cognitive representations underlie social attitudes?” Bulletin of the Psychonomic Society, 283,1990. 
[15] T. M.Ostrom, "The relationship between the affective, behavioral, and cognitive components of attitude,"Journal of Experimental Social Psychology, 51, pp. 12-30, 1969. https://doi.org/10.1016/002210316990003-1.

[16] R.P. Bagozzi, and R.E.Burnkrant, "Attitude organization and the attitude-behavior relation: a reply to Dillon and Kumar," Journal of Personality and Social Psychology, 371, pp.913-929, 1979.

[17] R.P., Bagozzi, "A field investigation of causal relations among cognitions, affect, intentions, and behavior", Journal of Marketing Research, November, 29, p.562-584, 1982.

[18] K.L. Duhaime, and Muller,Le comportement $d u$ consommateur,ÉditionGaëlan Morin, 1996, pp. 24-33.

[19] H.C.Triandis, Values, attitudes, and interpersonal behavior, Nebraska Symposium on motivation, 1979: Beliefs, Attitudes, and values. Lincoln, NE, University of Nebraska Press, pp.195-259, 1980.

[20] D. Darpy,la procrastination du consommateur: Une contribution à l'explication du report d'achat, D. dissertation, Dept. management, Paris IX-Dauphine Univ., 1999.

[21] J. A. Howard, Buyer Behavior in Marketing Strategy, Englewood Cliffs, NJ: Prentice Hall, 1994.

[22] R. W. Belk, Issues in the Intention-Behavior Discrepancy, In ShethJagdish N. Ed., Research in Consumer Behavior, CN:Greenwich: JAI Press, Vol.1, pp. 1-34, 1985.

[23] P. R. Warshaw, and F. D. Davis, "Disentangling behavioral intention and behavioral expectation". Journal of Experimental Social Psychology, 213, pp. 213-228, 1985. https://doi.org/10.1016/0022103185900.

[24] Juster F.T., "Consumer buying intentions and purchase probability: an experiment in survey design," American Statistical Association Journal, September, pp.658-696, 1966.

[25] D.Morrison, "Purchase intentions and purchase behavior", Journal of Marketing, 43, p.65-74, 1979.

[26] C.Dussart, Comportement du consommateur et stratégies de marketing, Montréal: Mc Graw Hill, 1983.

[27] L.F. Jamieson, and Bass F.M., "Adjusted stated intention to predict trial purchase of new products:a comparison of models and methods," Journal of Marketing Research, August, 26, pp.336-345, 1989.

[28] M.Fishbein, and I.Ajzen,Belief, attitude, intention, and behavior: An introduction to theory and research, Reading, Mass: Addison-Wesley Pub, Co, 1975

[29] B., Yoo, N., Donthu, "Developping and validating a multidimensional consumer-based brand equity scale", Journal of Business Research, 52, pp.1-142, 001.

[30] W. B., Dodds, K. B., Monroe, D., "Grewal, Effect of price, brand and store information on buyers' product evaluations", Journal of Marketing Research, 28, 3, pp.307-319, 1991.

[31] E. N., Berkowitz, J.R., Walton, "Contextual Influences on Consumer Price Responses: An Experimental Analysis", Journal of Marketing Research, 17,3, pp.349-358, 1980

[32] R.A. Peterson and A.A. Jolibert, "A Meta-Analysis of Country-ofOrigin Effects," Journal of International Business Studies, 264, 883900,1995. DOI: 10.1057/palgrave.jibs.8490824.

[33] G. Elliot., R.Cameron, "Consumer Perception of Product Quality and the Country-of-Origin Effect," Journal of International Marketing, Vol 2 , No. 2 , pp. $56,1994$.

[34] H. Nadiri and M. Tümer, "Influence of ethnocentrism on consumers" intention to buy domestically produced goods: An empirical study in North Cyprus," pp. 444-461, 2011.

[35] S. Rezvani, G.J. Dehkordi, M.S. Rahman, F. Fouladivandal, S. Eghtebasi, and M. Habibi,"A Conceptual Study on the Country of Origin Effect on Consumer Purchase Intention,” Asian Social Science, 8 12, pp. 205-2152012. 